\title{
EPIZOOTIC ULCERATIVE SYNDROME (EUS) FISH DISEASE CHRONOLOGY, STATUS AND MAJOR OUTBREAKS IN THE WORLD
}

\author{
Devashish KAR * and Roy AUROBINDO ** \\ * Ex-Assam (Central) University, Division of Wetlands, Fisheries and Aquaculture, Department of Life \\ Science, Silchar, Assam, India, IN-788011, devashishkar@yahoo.com, Conservation Forum, Silchar, \\ Assam, India, IN-788005. \\ ** Ex-National Institute of Virology, Pune India, IN-411001, aroy45@gmail.com.
}

DOI: 10.2478/trser-2021-0012

KEYWORDS: wetlands, habitat, fish, Epizootic Ulcerative Syndrome.

\begin{abstract}
Epizootic Ulcerative Syndrome (EUS) has been causing large-scale mortality among the freshwater fishes of the globe since the 1070s.

The symptoms include large haemorrhagic cutaneous ulcers, epidermal degeneration and necrosis followed by sloughing of scales. There have been many studies on EUS throughout the world. In India, since the initiation of EUS, in 1988, our study tried to reveal the aetiology of the disease through extensive and intensive studies on different aspects, like limnological, physical, chemical, bacteriological, fungal, viral including electron microscopic studies. Details of EUS investigation has been discussed in the present paper.

RÉSUMÉ: Syndrome ulcératif épizootique (SUE) chronologie des maladies des poissons, situation et principaux foyers dans le monde.

Le syndrome ulcératif épizootique (SUE) est à l'origine d'une mortalité à grande échelle chez les poissons d'eau douce du globe depuis les années 1070.

Les symptômes comprennent de grands ulcères cutanés hémorragiques, une dégénérescence et une nécrose de l'épiderme suivies d'une desquamation. De nombreuses études sur le SUE ont été réalisées dans le monde entier. En Inde, depuis le lancement du SUE, en 1988, notre étude a tenté de révéler l'étiologie de la maladie par des études approfondies et intensives sur différents aspects, comme les études limnologiques, physiques, chimiques, bactériologiques, fongiques, virales, y compris au microscope électronique. Les détails de l'enquête de l'EUS ont été abordés dans la présente travaux.

REZUMAT: Sindromul ulcerativ epizootic (EUS) cronologia bolii peștilor, starea și focarele majore din lume.

Sindromul ulcerativ epizootic (EUS) a provocat mortalitate pe scară largă în rândul peștilor de apă dulce de pe glob încă din anii 1070.

Simptomele includ ulcere cutanate hemoragice mari, degenerescență epidermică și necroză, urmate de pierderea solzilor. Au existat numeroase studii asupra EUS în întreaga lume. În India, de la apariţia EUS, în 1988, studiul nostru a încercat să dezvăluie etiologia bolii prin studii ample și intensive asupra diferitelor aspecte, cum ar fi limnologic, fizic, chimic, bacteriologic, fungic, viral, inclusiv studii microscopice electronice. Detaliile anchetei EUS au fost discutate în prezenta lucrare.
\end{abstract}




\section{INTRODUCTION}

The hitherto unknown virulent enigmatic EUS has been sweeping unabated, unhindered semi-globally causing large-scale mortality among the freshwater fishes (FW), causing fear psychosis among the fish eaters, leading to untold hardship to the fishermen and devastating the economy of some countries (Kar, 2015).

Following the report of mycotic granulomatosis (MG) in Japan in 1971 (Egusa and Masuda, 1971; Miyazaki and Egusa, 1972), the earliest reports of EUS could be traced from the red spot disease (RSD) in Australia, sometime in 1972 (Mckenzie and Hall, 1976; Callinan et al., 1989) and Papua New Guinea in 1974 (Coates et al.,1989), from where, EUS has been sweeping almost in a chronological manner through most of the South-East and South Asian countries, like Indonesia (1980), Malayasia (1979-1983) (Shariff and Law, 1980), Thailand (1985) (Tonguthai, 1985), Kampuchea and Lao (1984) (Lilley et al., 1992), Myanmar (19841985) (Soe, 1990); Sri Lanka (1987) (Costa and Wijeyarantne, 1989); Bangladesh (March, 1988) (Barua, 1994), until, EUS had reached India through the Barak Valley region of Assam during July, 1988, and, has been sweeping the region, even today, causing large-scale mortality among the freshwater fishes (Kar, 2007, 2013, 2015, 2019).

Thus, EUS had been reported from an increasing number of countries, where it had become quikly widespread in both cultured and wild fish populations (Blazer et al., 2002).

Likewise, ulcerative mycosis (UM), an ulcerative syndrome was reported in estuarine fish on the East Coast of the United States of America since the early 1980s. This had been ascribed to the same cause, according to some researchers (Blazer et al., 2002).

The pattern of spread to distinctly separate geographic locations within a relatively short period of time had been considered by some quarters as consistent with the progressive dissemination of a single infectious agent (Lilley et al., 1997; Baldock et al., 2005; Kar, 2007, 2010, 2013, 2015, 2019).

Initially, the syndrome was called by various names, like ulcerative disease syndrome (UDS), fish disease syndrome (FDS), etc. Finally, the name epizootic ulcerative syndrome (EUS), was adopted in 1986 at the meeting of the Experts Consultation Committee on Ulcerative Fish Diseases in Bangkok (FAO, 1986). Outbreaks of EUS have been often reported in a large number of countries in the Asia-Pacific region.

In India, widespread initiation of outbreak of EUS started from Barak Valley region of Assam since July, 1988 (Kar, 2015). Outbreaks of EUS in India have been comprehensively reviewed at various fora (The Zoological Society of Assam, 1988; Jhingran and Das, 1990; ICSF, 1992; Mohan and Shankar, 1994, etc.).

From Barak Valley region of Assam, EUS has been spreading and sweeping, almost unabated and more or less in a chronological manner through other regions of India, notably, West Bengal (1989), Bihar (1989), Odisha (1989), UP (1990), MP (1990), Maharastra (19911992), Karnataka (1993), Goa (1993), Tamil Nadu (1993), Andhra Pradesh (1992-1993), Kerala (1994-1995), till EUS had reached Pakistan during 1998-1999 and is said to be progressing further.

EUS is characterized by the occurrence of large haemorrhagic or necrotic ulcerative lesions on the bases of the fins and other parts of the body which becomes larger inflamed areas with acute degeneration of epidermal tissues (Kar, 2015). 


\section{Initiation of study on EUS and different affected species}

The first author had begun his study with the ichthyological survey of the lentic water bodies in Barak Valley region of Assam $\left(24^{\circ} 10^{\prime} \mathrm{N}-93^{\circ} 15^{\prime} \mathrm{E}\right)$ with the identification of the four most widely-affected species of fishes (due to EUS) during July, 1988.

These are:

Macrognathus aral, which portrays lesions on the skin generally in the abdomen and occasionally in the caudal region;

Channa punctatus, which shows lesions on the skin generally at the base of the caudal peduncle and sometimes show reddish swollen eyes (exophthalmos);

Mystus vittatus, which depicts amber-coloured lesions at the base of the rayed dorsal fin and sometimes at the base of the caudal fin;

Puntius conchonius, which exhibits amber-coloured lesions at the base of the dorsal and caudal fins and sometimes in other parts of the body.

Other species affected by the present epidemic, during July, 1988, but not very widely, include the following: Mastacembelus armatus, Macrognathus pancalus, Salmostoma bacaila, Gudusia chapra, Badis badis, Glossogobius giuris, Ailia coila, Lepidocephalichthys guntea, Clarias batrachus, Cirrhinus mrigala, C. reba, Parambassis ranga, etc. Wallago attu and Hilsa (Tenualosa) ilisha have not been found to be widely affected by the prevailing epidemics. Among the Indian major carps, during July, 1988, barring a few Catla catla and Cirrhinus mrigala, none of the other Indian major carps were found to be affected by EUS. Nevertheless, Amblypharyngodon mola, Ctenopharyngodon idellus, Rasbora daniconius, Puntius ticto and Channa marulius have been found to be affected only in certain areas of the district at the beginning.

Our continued study revealed that, during the period 1992-1994, the following species had been found to be very severely affected by EUS: Parambassis ranga, Chanda nama, Nandus nandus, and Glossogobius giuris. Some of the other species affected by EUS, but to a lesser extent during this period, included Mastacembelus armatus, M. pancalus, Xenentodon cancila, and Colisa fasciatus, etc.

Our subsequent studies indicated that the following species of fishes have been severely-affected by EUS, since 1995, particularly, during the period November-February, causing large-scale mortality among them: Channa striata, C. punctatus, Anabas testudineus, and Clarias batrachus.

Thus, there has been a differential pattern of spread of EUS among different fish species during different seasons and years (Kar, 2015).

Moreover, our study also revealed a periodicity in the magnitude of the disease among the four most widely affected species (Kar, 2015):

(a) From around mid-July to mid-August, 1988:

Mystus vittatus > Channa punctatus > Macrognathus aral > Puntius conchonius;

(b) From around mid-August to first week of September, 1988:

Mystus vittatus > Macrognathus aral > Puntius conchonius > Channa punctatus;

(c) From around first week of September to around last week of September, 1988:

Mystus vittatus > Puntius conchonius > Channa punctatus > Macrognathus aral;

(d) From around last week of September to around third week of October, 1988:

Puntius conchonius > Channa punctatus > Macrognathus aral > Mystus vittatus. 
Our 2002-2004 study revealed that, the highest mortality rate has been found among Cirrhinus mrigala, Channa spp., Puntius spp., Labeo spp., and Clarias batrachus. Specific Death Rate (SDR) due to EUS calculated on the basis of nmber of deaths during a year/midyear population (total number of species) x 100, was found to be $(22 / 38)$ x $100=57.89 \%$.

During the said period, the killing power of EUS has been represented by the Case Fatality Ratio (CFR) = Total number of deaths due to EUS/Total nomber.of cases due to EUS $\mathrm{x}$ 100. CFR has been calculated species wise and has been found to be high among Cirrhinus mrigala (83.72\%), followed by Puntius ticto (75\%), Channa marulius (70\%), Mastacembelus armatus 69.23\%), Anabas testudineus (53.85\%), and, so on (Kar, 2015).

\section{Epidemiology of EUS at the international level}

With regard to the Global scenario, more than 100 fish species have been reported to be affected by EUS (Lilley et al., 1992), but, only relatively few reports have been confirmed by demonstrating the presence of the infecting agent.

Some commercially important species are considered to be particularly resistant to EUS. But, not much studies have been done to confirm these observations and investigate the mechanism of resistance. Species reported to be unaffected by EUS outbreaks include the Chinese carps, tilapias, and milkfish (Chanos chanos). Hatai (1994) experimentally injected catfish (Parasilurus asotus), loach (Misgurnus anguillicaudatus) and eel (Anguilla japonica) with hyphae of $A$. invadans and found them to be refractory to infection. Wada et al. (1996), and Sharifpour (1997) experimentally injected common carp (Cyprinus carpio) with zoospores of Aphanomyces from MG and EUS outbreaks respectively, and, demonstrated that fungal growth was suppressed by an intense inflammatory response.

Humphrey and Pearce (2006) had reported that, in the Northern Territory of Australia, EUS had been reported in archer fish (Toxotes chartareus), barramundi (Lates calcarifer), bony bream (Nematolosa erebi), chanda perch (Ambassis agassizii), fork-tailed catfish (Arius sp.), etc.

Notwithstanding the above, in Pakistan, EUS, appeared to be confined to the regions of rivers Chenab and Ravi and their associated irrigation canals in the districts of Kasur, Lahore, Gujranwala, and Sialkot. Wide range of infections and large-scale mortalities had occurred among some of the ichthyospecies, viz., Channa punctatus, Channa marulius, Wallago attu, and Puntius sp., etc.

Concomitant to above, in Bangladesh, the most-affected fish species were the Puntius spp., Channa spp., Mastacembelus spp., and, so on. Moreover, there had been reports of variations in the status of susceptibility at the species level among the different genera as revealed during selection of candidate species for aquaculture.

Khan and Lilley (2002) found differences in the occurrence of lesions among different habitats. Moreover, fishes collected by little uncommon fishing gears, like the seine nets, seemed to have a lower prevalence of EUS lesions as compared to fishes collected by more common fishing gears, like the scooping nets, spears, etc. The latter often damaged the body of the fish and could make it more susceptible to disease.

Moreover, the most severely affected species in natural outbreaks are generally bottom dwellers (Llobrera and Gacutan, 1987; Chondar and Rao, 1996) or the fishes which possess air-breathing organs. Among the snakeheads, no particular size group appears to be more susceptible, with affected fish usually ranging from 40 to $900 \mathrm{~g}$ (Cruz-Lacierda and Shariff, 1995). Moreover, the IMC juveniles were more affected than the adults (AAHRI, ACIAR, IoA, and NACA, 1997). 
Further, several EUS-affected snakehead and clariid catfish species occur in Africa and in Central Asia, suggesting that, there is potential for further spread of the disease to these areas, and, the EUS did spread.

In 2006, fish caught in the Chobe-Zambezi River were found to be EUS-affected as confirmed by the OIE-FAO- supported reference Laboratory in Thailand. In 2007, the disease was reported in Namibia and Zambia. EUS was reported in the Kafue River and in its tributaries (Chongwe River) in 2010 and 2011 respectively.

The fishes of lake Kariba and lake Cahora Bassa (large impoundments in lower part of Zambezi River supporting significant fisheries) were EUS-affected. Lake Kariba has one of the largest aquaculture facilities in sub-Saharan Africa. In 2010, EUS was reported from the Okavango Delta in Botswana and in 2011 from the Western Cape Province of South Africa. Biodiversity of the fishery, as a result, had been threatened, thus, posing food insecurity to $>700,000$ people in the region.

The Geographic Information System (GIS) had helped to map the distribution of the disease. Results of the study had implicated a number of predisposing environmental factors.

The latest outbreak of EUS had been reported from Canada. A new susceptible species of brown bullhead, Ameiurus nebulosus seemed to had been affected by EUS.

It appeared that the disease has potential to spread further, because of its epizootic nature and broad susceptible host range.

\section{To prepare a working hypothesis}

Based on the analysis of time, place and fish data, working hypotheses are usually developed for further investigation. These may concern one or more of the following:

(a) Whether the outbreak is common source or propagating;

(b) If a common source, whether it is point or multiple exposure;

(c) The mode of transmission: contact, vehicle or vector. Any hypothesis should be compatible with all the facts;

(d) Corrective action could be taken based on the more realistic hypotheses.

\section{Intensive follow up}

This generally includes clinical, pathological, and microbiological examinations, together with examinations of water quality data and recent meteorological data. Epidemiological follow-up will include detailed analyses of these data as well as the search for additional cases on other premises. Flow charts of management and movements of fish, water, and equipment, for example, may be required as part of this process. Transmission trials may be necessary where additional infectious agents, such as bacteria or ectoparasites, are suspected as component causes of the outbreak.

Details of the outbreak of EUS, including the Inter- and Intra-continental status had already been elucidated earlier.

\section{Management of epidemiologic episodes}

Epidemiological evidence suggests that, EUS outbreaks in farmed fish are more severe when stocking densities are high. Stocking densities should be maintained as low as possible and farmed populations subjected to minimal stress. In particular, fish could be monitored to ensure that bacterial and parasitic skin pathogens do not cause problems. Further, the abiotic factors, like DO are to be at the optimum level. EUS-resistant fishes are preferably to be cultured during the EUS-outbreak period. 
Concomitant to above, from an epidemiological perspective, and to accommodate the apparently multifactorial nature of EUS, Lilley et al., (1998) used the concepts of "necessary cause", "component cause" and "sufficient cause". Each combination of various "component causes" which result in disease is known collectively as a "sufficient cause" for that disease. However, under different circumstances, different combinations of "component causes" may constitute "sufficient cause" for a disease and these "sufficient causes" for a particular disease have in common at least one "component cause", known as "necessary cause" which must always be present for that disease to occur.

\section{Background involvement in EUS}

Bacterial culture revealed occurrence of haemolytic E. coli, Aeromonas hydrophila, Pseudomonas aeruginosa, Klebsiella sp., Staphylococcus epidermidis in the surface lesions as well as in the gut, liver, gills, heart, kidney. and gonads of sick fishes, all of which have been found to be sensitive to Chloramphenicol, Septran, Gentamycin, etc.

\section{Mycotic involvement in EUS}

Fungal isolation revealed the occurrence of Aphanomyces sp. with concomitant occurrence of the same fungal genus in histological sections of EUS-affected fishes.

\section{Viral involvement in EUS}

Inoculation of $10 \%$ tissue homogenate of EUS-affected Clarias batrachus into $80 \%$ confluent monolayer form BF2 and RTG fish cell lines in Leiboitz L-15 medium, revealed progressive CPE which was passable in subsequent cultures, thus, indicating the "isolation" of virus. The filterable biological particles were different from those described by Frerichs et al. (1986).

Further, recent studies revealed the detection of Ranavirus infection in cultivated carps of North-East India (Kar, 2007, 2013, 2015, 2019; Riji et al., 2016).

\section{Electron microscopic studies}

Electron microscopic studies with the ultra-thin sections of still-occurring EUSaffected fish tissues, revealed the presence of virus-like particles (inclusion bodies), and, preliminarily, the picobirna virus has been electron microscopically identified as the primary aetiological agent of EUS (Kar, 2015).

\section{Summary of EUS investigation}

EUS has been causing large-scale mortality among the freshwater fishes since 1988, initially affecting four species of fishes very widely. Our study revealed fluctuation in the intensity of the disease in relation to species affected. Large haemorrhagic cutaneous ulcers, epidermal degeneration and necrosis followed by sloughing of scales are the principal symptoms of EUS. Low total alkalinity (TA) of water could be a pre-disposing "stress factor". Sick fishes show low haemoglobin and polymorphs, but high ESR and lymphocytes. Communicative nature of EUS revealed variation in time gap between fish and infection in different species. Inoculation of microbes in the test animals did not reveal of any sign of ulcerations for two years. Bacterial culture revealed occurrence of haemolytic E. coli, Aeromonas hydrophila, Pseudomonas aeruginosa, Klebsiella sp., and Staphylococcus epidermidis in the surface lesions as well as in the gut, liver, gills, heart, kidney, and gonads of sick fishes, all of which have been found to be sensitive to Chloramphenicol, Septran, Gentamycin, etc. Fungal isolation revealed the occurrence of Aphanomyces sp. with concomitant occurrence of the same fungal genus in histological sections of EUS-affected fishes. Histopathological (HP) studies showed focal areas of increased fibrosis and chronic inflammatory cell infiltration in muscles, focal areas of fatty degeneration of hepatocytes surrounding the portal triads in the liver. 


\section{CONCLUSIONS}

EUS is a global pandemic. EUS attack is specific to fish only.

Radioactivity had no role in EUS infection.

Organic pollution of water and soil were not the reasons for EUS pandemic.

EUS pandemic was not due to any heavy metallic contamination.

EUS has associated bacteria, fungi and viruses. Bacterial flora causing co-infection

included E.coli, Pseudomonas aeruginosa, Klebsiella sp., Aeromonas hydrophila, Staphylococcus epidermitis, etc.

Aphanomyces invadans was the principal mycotic flora associated with EUS infection. A primary viral aetiology was established in tissue culture.

Electron microscopic study revealed it to be a birna virus.

Effective measures must be adopted to prevent fish mortality.

EUS vaccine yet to be developed. Vaccine preparation for EUS to be intiated effectively. 


\section{ACKNOWLEDGEMENTS}

The authors utilise the privilege of this opportunity to express their deep sense of gratitude to all those (particularly the field level persons and the fisherfolk) who were directly or indirectly involved in this piece of work. 


\section{REFERENCES}

1. AAHRI, ACIAR, IoA and NACA, 1997 - Epizootic Ulcerative Syndrome (EUS) of fishes in Pakistan. A report of the findings of an ACIAR/ DFID-funded mission to Pakistan, 9e19.

2. Baldock F. C., Blazer V., Callinan R., Hatai K. and Karunasagar I., 2005 - Outcome of a short expert consultation on epizootic ulcerative syndrome (EUS): re-examination of causal factors, case definition and nomenclature, in Walker P., Laster R. and Bondad-Reantaso M. G. (eds), Disease in Asian Aquaculture, V, Fish Health Section, Asian Fisheries Society, Manila, Phillippines, 555-585.

3. Blazer V. S., Lilley J., Schill W. B., Kiryu Y., Densmore C. L., Panyawachira V. and Chinabut S., 2002 - Aphanomyces invadans in Atlantic menhaden along the east coast of the United States, Journal of Aquatic Animal Health, 14, 1-10.

4. Barua G., 1994 - The status of epizootic ulcerative syndrome of fish of Bangladesh, 13e20, in Roberts R. J., Campbell B., Mac Rae I. H. (eds), Proceedings of the ODA Regional Seminar on Epizootic Ulcerative Syndrome, 25e27 January, 1994, Aquatic Animal Health Research Institute, Bangkok.

5. Callinan R. B., Fraser G. C. and Virgona J. L., 1989 - Pathology of red spot disease in sea mullet, Mugil cephalus L. from Eastern Australia, Journal of Fish Disease, 12, 467e479.

6. Coates D., Nunn M. J. and Uwate K. R., 1989 - Epizootic ulcerative disease of freshwater fish in Papua New Guinea, Science of New Guinea, 15, $1 \mathrm{e} 11$.

7. Chondar S. L. and Rao P. S., 1996 - Epizootic Ulcerative Syndrome Disease to fish and its control: a review, World Aquaculture 1996, Book of Abstracts, World Aquaculture Society, Bangkok, 77.

8. Costa H. H. and Wijeyaratne M. J. S., 1989 - Epidemiology of epizootic ulcerative syndrome occurring for the first time among fishes in Sri Lanka, Journal of Applied Ichthyol, 1, 48e52.

9. Cruz-Lacierda E. R. and Shariff M., 1995 - Experimental transmission of epizootic ulcerative syndrome (EUS) in snakehead, Ophicephalus striatus, in Shariff M., Arthur J. R., Subasinghe R. P. (eds), Diseases in Asian Aquaculture II. Fish Health Section, Asian Fisheries Society, Manila, Philippines, 327e336.

10. Egusa S. and Masuda N., 1971 - A new fungal disease of Plecoglossus altivelis, Fish Pathology, 6, 41e46.

11. FAO, 1986 - Report of the expert consultation on Ulcerative Fish Diseases in the Asia-Pacific Region, (TCP/RAS/4508), Bangkok, August 1986, FAO, Regional Office for Asia and the Pacific, Bangkok.

12. Frerichs G. N., Millar S. D. and Roberts R. J., 1986 - Ulcerative rhabdovirus in fish in Southeast Asia, Nature, 322, 216.

13. Hatai K., 1994 - Mycotic granulomatosis in ayu (Plecoglossus altivelis) due to Aphanomyces piscicida, in Roberts R. J., Campbell B. and MacRae I. H., (eds), Proc. ODA Regional Seminar on Epizootic Ulcerative Syndrome, 25e27 January 1994, Aquatic Animal Health Research Institute, Bangkok.

14. Humphrey J. D. and Pearce M., 2006 - Epizootic Ulcerative Syndrome (Red-spot Disease), Fishnote,Northern Tereritory Government, Australia, 1e4.

15. ICSF, 1992 - Enigma of EUS. Consultation on Epizootic Ulcerative Syndrome vis-a-vis the environment and the people. 25e26 May, 1992, Trivandrum, Kerala, International Collective in Support of Fishworkers, Madras, India, 40.

16. Jhingran A. G. and Das M. K., 1990 - Epizootic Ulcerative Syndrome in Fishes, Bulletin of the Central Inland Capture Fisheries Research Institute (No. 65), CIFRI, Barrackpore, India, 1-14.

17. Kar D., 2007 - Fundamentals of Limnology and Aquaculture Biotechnology, 609, Daya Publishing House (New Delhi).

18. Kar D., 2010 - Biodiversity Conservation Prioritisation, 167, Swastik Publications (New Delhi). ISBN:978-93-80138-26-8. 
19. Kar D., 2013 - Wetlands and Lakes of the World, 1st Edition, 687, Springer (London)., Print ISBN 978-81-322-1022-1.

20. Kar D., 2015 - Epizootic Ulcerative Fish Disease Syndrome, 1st Edition, 293, Elsevier, (Academic Press), USA, ISBN: 9780128025048.

21. Kar D., 2019 - Wetlands diversity and their fishes in Assam, India, Transylvanian Review of Systematical and Ecological Research, 21.3, The Wetlands Diversity, 47-94.

22. Khan M. H. and Lilley J. H. 2002 - Risk factors and socio-economic impacts associated with epizootic ulcerative syndrome (EUS) in Bangladesh, 27-39, in Arthur J. R., Phillips M. J., Subasinghe R. P., Reantaso M. B. and MacRae I.H. (eds), Primary Aquatic Animal Health Care in Rural, Small-scale, Aquaculture Development, FAO Fisheries Technical Papers, 406.

23. Lilley J. H., Callinan R. B., Chinabut S., Khanchanakhan S., MacRae I. H. and Phillips M. J., 1998 - Epizootic Ulcerative Syndrome (EUS) Technical Handbook, The Aquatic Animal Health Research Institute, Bangkok, 88.

24. Lilley J. H., Phillips M. J. and Tonguthai K., 1992 - A review of epizootic ulcerative syndrome (EUS) in Asia, Aquatic Animal Health Research Institute and Network of Aquaculture Centres in Asia-Pacific, Bangkok, 73.

25. Lilley J. H., Hart D., Richards R. H., Roberts R. J., Cerenius L. and Söderhäll K., 1997 - PanAsian spread of single fungal clone results in largescale fish-kills, Veterinary Record, 140, $653 \mathrm{e} 654$.

26. Llobrera A. T. and Gacutan R. Q., 1987 - Aeromonas hydrophila associated with ulcerative disease epizootic in Laguna de Bay Philippines, Aquaculture, 67, $273 \mathrm{e} 278$.

27. Mckenzie R. A. and Hall W. T. K., 1976 - Dermal ulceration of mullet (Mugil cephalus), Australian Veterinary Journal, 52, 230e231.

28. Mohan C. V. and Shankar K. M., 1994 - Epidemiological analysis of epizootic ulcerative syndrome of fresh and brackishwater fishes of Karnataka, India, Current Science, 66, 656e658.

29. Miyazaki T. and Egusa S., 1972 - Studies on mycotic granulomatosis in freshwater fish I, Mycotic granulomatosis in goldfish, Fish Pathology, 7, 15e25 (in Japanese).

30. Riji J. K., Rosalind M., Kar D., Md Mansoor, Kumar, Mahesh, Singha, Ratnabir, Waikhom, Gushein Z., 2016 - Detection of Ranavirus infection in cultivated carps of North-East India, Fish Pathology, 51, 66-74.

31. Shariff M. and Law A. T., 1980 - An incidence of fish mortality in Bekok River, Johore, Malaysia, in Proceedings of International Symphosium on Conservationand Input from Life Sciences, 27e30 October 1980, Universiti Kebangsaan, Bangi, Selangor, Malaysia.

32. Soe U. M., 1990 - Myanmar report, in Regional Research Programme on Relationships between Epizootic Ulcerative Syndrome in Fish and the Environment, NACA, Bangkok, 35e38.

33. Sharifpour I., 1997 - Histology of the Inflammatory Response of the Carp (Cyprinus carpio L.) to Various Stimuli (Ph.D. thesis), University of Stirling, Scotland, 1-377.

34. Tonguthai K., 1985 - A preliminary account of Ulcerative Fish Diseases in the Indo-Pacific Region (a comprehensive study based on Thai experiences), National Inland Fisheries Institute, Bangkok, Thailand, 39.

35. Wada S., Rha S.., Kondoh T., Suda H., Hatai K. and Ishii H., 1996 - Histopathological comparison between ayu and carp artificially infected with Aphanomyces piscicida, Fish Pathology, 31, 71e80.

36. Zoological Society of Assam, 1988 - in Proceedings of the Symposium on Recent Outbreak of Fish Diseases in North Eastern India, 30 December 1988, Organised by Zoological Society of Assam, Guwahati, Assam, India, 23. 